\title{
First occurrence of parasitoid Hemencyrtus herbertii Ashmead (Hymenoptera: Encyrtidae) in pupae of Hemilucilia flavifacies Enderlein (Diptera: Calliphoridae) in Brazil
}

\section{Primeira ocorrência do parasitóide Hemencyrtus herbertii Ashmead (Hymenoptera: Encyrtidae) em pupas de Hemilucilia flavifacies Enderlein (Diptera: Calliphoridae) no Brasil}

\author{
Carlos Henrique Marchiori, ${ }^{\star 1}$ Luiz Alex Pereira, ${ }^{\star \star}$ Otacilio Moreira da.Silva Filho, ${ }^{\star *}$ Lalyne Christine Silva Ribeiro, ${ }^{\star *}$ \\ Vanessa Rodrigues Borges**
}

\begin{abstract}
This study report first occurrence of parasitoid Hemencyrtus herbertii Ashmead (Hymenoptera: Encyrtidae) in pupae of Hemilucilia flavifacies Enderlein (Diptera: Calliphoridae) in Brazil. The pupae were obtained by the flotation method. They were individually placed in gelatin capsules until the emergence of the adult flies or their parasitoids. The overall prevalence of parasitism was $19,8 \%$.
\end{abstract}

Keywords: Hymenoptera, Diptera, urban area, medical-veterinary importance.

\section{Resumo}

Este estudo relata a primeira ocorrência do parasitóide Hemencyrtus herbertii Ashmead (Hymenoptera: Encyrtidae) em pupas de Hemilucilia flavifacies Enderlein (Diptera: Calliphoridae) no Brasil. As pupas foram obtidas pelo método de flutuação. Elas foram individualizadas em cápsulas de gelatina e mantidas até a emergência das moscas e/ou dos parasitóides. A prevalência total de parasitismo foi de $19,8 \%$.

Palavras-chave: Hymenoptera, Diptera, área urbana, importância médico-veterinária.

Diptera is an optimal model to study synanthropy, not only for it ecological importance, but also by medical-veterinary aspects, as vectors of etiological agents, such amoeba cysts, helminth eggs, pathogenic enterobacteria, viruses and fungi (Geenberg, 1971 Princeton Univ. Press. Princeton, N.J.; D'Almeida, 1992 Mem. Inst. Oswaldo Cruz, v. 87, n. 3, p. 454-457). According to D'Almeida \& Lopes (1983 Arq. Univ. Fed. Rur. Rio de J., v.6, p. 39-48) Hemilucilia flavifacies Enderlein (Diptera: Calliphoridae) did not show any preference for inhabited areas in Rio de Janeiro, in previous researches on favourite breeding substrates, performed in the zoo.

The study was conducted in an urban area of the College of Agronomy (Faculdade de Agronomia), located in Itumbiara County, State of Goias, Central Brazil (18 ${ }^{\circ} 25^{\prime}$ S; 49 $43^{\prime}$ ' W). Flies were attracted to traps made of dull black tin foil cans, measuring $19 \mathrm{~cm}$ in height and $9 \mathrm{~cm}$ in diameter, with two Venetian blind type openings placed in the inferior third to allow insects entering. To the upper part of the cans, nylon funnels with opened extremities and bases turned down, were attached. These traps were then wrapped with plastic bags, which after removal would allow the capture of flies and parasitoids (Figure 1). Chicken deposited on top of a soil layer were placed as baits inside the cans. Five of these traps were suspended on Eucalyptus sp. trees at $1 \mathrm{~m}$ above the soil level, $2 \mathrm{~m}$ apart from each other and $50 \mathrm{~m}$ away from a domestic garbage deposit. The specimens collected were taken to the laboratory, killed with ethyl ether and preserved in $70 \%$ ethanol for further identification. After retrieval of insects, the traps contents were placed into plastic containers containing a layer of sand to serve as substrate for larvae population. After remaining 15 days in the field the sand of these containers was sifted for extraction of pupae obtained in a natural environment. These pupae were than individually transferred to gelatin capsules (number 0 ) to obtain flies and/or parasitoids.

The prevalence of parasitism was computed by the following formula: $P=$ (parasite pupae/total pupae) $\times 100$.

* Instituto Luterano de Ensino Superior de Itumbiara-ILES-ULBRA, Av. Beira Rio, 1001, 75500-000, Itumbiara, GO, pesquisa.itab@ulbra.br

** Alunos do Curso de Biologia do Instituto Luterano de Ensino Superior de Itumbiara-ILES-ULBRA 
From March of 2001 to January of 2002, 16 specimens of Hemencyrtus herbertii Ashmead (Hymenoptera: Encyrtidae) were collected from 81 pupae Hemilucilia flavifacies Enderlein (Diptera: Calliphoridae). The prevalence of parasitism was $19,8 \%$. The $H$. herbertii presented himself as gregarious, emerging several individuals from the same pupary, a poliembrionary is considered very ordinary. The species $H$. herbertii occurs almost everywhere around the world and lives associated to Diptera, emerging from their pupa shell. Muscoids dipterous control using insecticides usually selects resistant populations, being just a palliative. Natural regulators, such as parasitoids are agents responsible for reduction of fly populations. The results obtained with this research allow us to stretch the occurrence of $H$. herbertii on a new host.

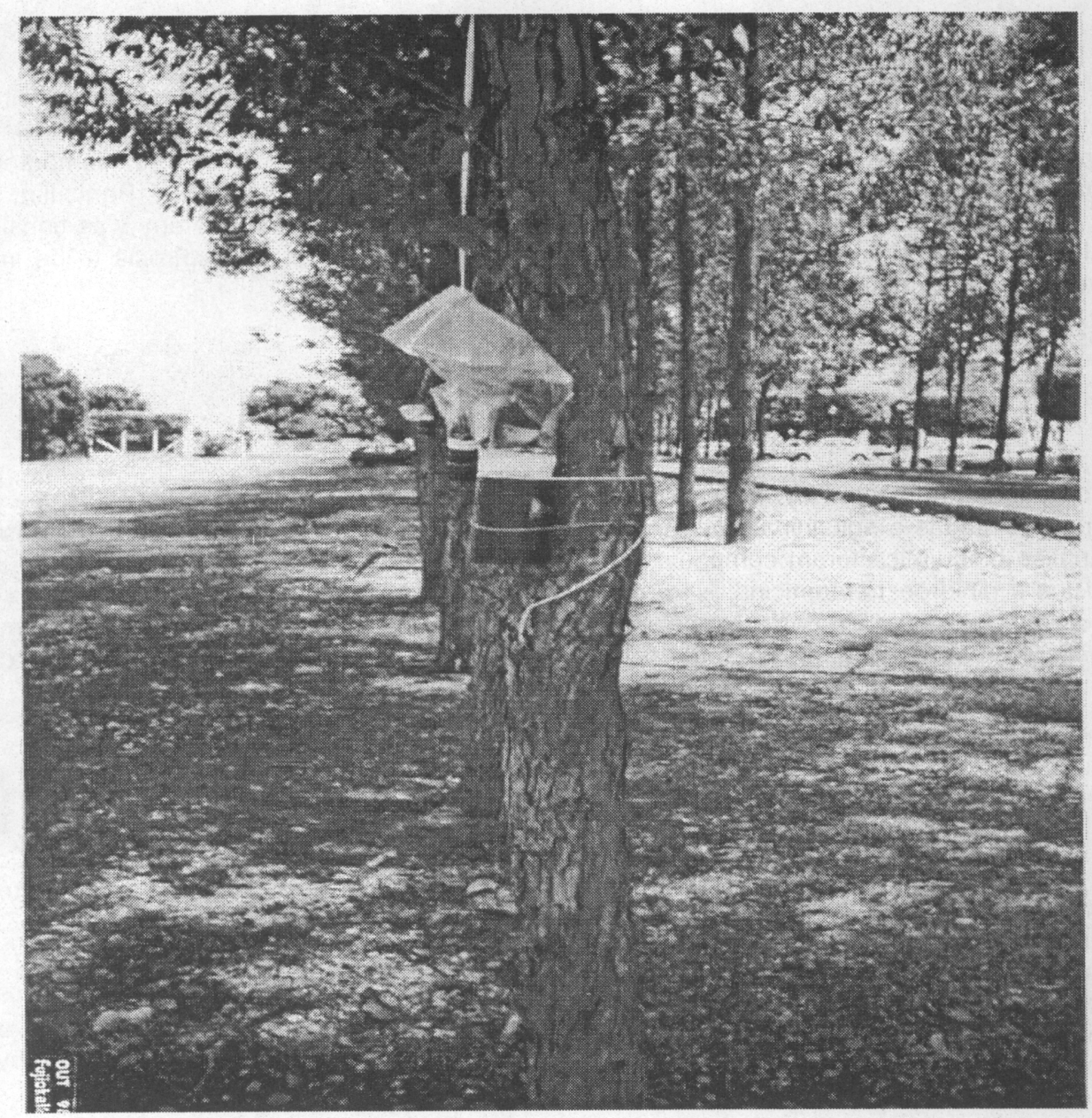

Figure 1: General aspect of trap 